\title{
MEMETAKAN PERUBAHAN ORGANISASI DALAM DESAIN LEARNING ORGANIZATION PADA USAHA KECIL MENENGAH DI KOTA MALANG
}

\author{
Sugeng Mulyono \\ Fakultas Ekonomi dan Bisnis, Universitas Gajayana \\ sugengmulyono45@yahoo.co.id \\ Enlik Kresnaini \\ Fakultas Ekonomi dan Bisnis, Universitas Gajayana
}

\begin{abstract}
This research aims at analyzing the implementation of learning organization at small and medium enterprises (SMEs); the effects of learning organization on individuals' ability; the effects of individuals' ability on SMEs changes; and the effects of learning organization on changes of SMEs. The population of this research is all SMEs located in Malang and the samples are 298 SMEs taken through multi stages sampling. The primary data were collected using a questionare and interviews, whereas the secondary were obtain from relevant documents. The collected data were analyzed using descriptive and structural equational modelling (SEM). The results show that learning organization has a significant positive effect on individuals' ability; the individuals' ability has a significant positive effect on changes of SMEs; and learning organization has a significant positive effect on changes of SMEs, as indicated by C.R $>2$ and value of $P<0,05$.
\end{abstract}

Keywords: learning organization, individual ability, organization changing

\section{PENDAHULUAN}

Ditengah persaingan yang semakin ketat dan peningkatan keinginan pelanggan terhadap produk berkualitas mengharuskan organisasi (perusahaan) melakukan peningkatan kapasitas sumber daya manusia secara optimal agar mampu merespon perubahan eksternal secara memadai. Perubahan lingkungan yang cepat menuntut setiap organisasi maupun bisnis segera menanggapi dan beradaptasi. Sebab dalam situasi lingkungan yang semakin kompetitif, salah satu faktor penentu keberhasilan maupun kegagalan organisasi adalah sumber daya manusia yang mendukung operasionalisasinya (Madan et al., 2010).

Perubahan lingkungan yang semakin cepat menuntut setiap organisasi untuk segera melakukan revitalisasi anggotanya melalui proses pembelajaran secara berkesinambungan agar memiliki daya tanggap dan daya adaptasi yang cepat terhadap dinamika eksternalnya. Kemajuan teknologi dan ilmu pengetahuan serta 
perubahan ekonomi mengharuskan organisasi ataupun bisnis membuat transformasi pengetahuan dan ketrampilan untuk merespon perubahan lingkungan (Robbins dan Judge 2009).

Organisasi ataupun individu tidak dapat menghadapi perubahan dengan cara menentang melainkan perlu mengelolanya melalui adaptasi diri. Senge (1994) menganjurkan bahwa orang yang ingin bersaing dalam lingkungan bisnis harus menjadikan pribadi maupun organisasinya sebagai pembelajar melalui adaptasi dengan lingkungan secara terus-menerus. Kemampuan mengantisipasi perubahan ini tergantung pada kreativitas, inovasi dan skill para anggota organisasi. Menumbuhkan kemampuan tersebut dapat dilakukan melalui pelatihan dengan proses pembelajaran secara berkesinambungan. Organisasi pembelajaran (learning organization) selalu memberikan peluang kepada anggotanya agar senantiasa melakukan perbaikan diri demi meraih keberhasilan kerja (Dessler 2008; Robbins dan Judge 2009).

Organisasi yang berfokus pada keunggulan daya saing berkelanjutan menuntut setiap anggotanya mempunyai ketangguhan dalam menghadapi perubahan yang cepat dan tingkat persaingan yang ketat. Kondisi ini telah mendorong pembentukan "masyarakat” pengetahuan yang anggotanya terdiri dari individu yang memiliki kesadaran untuk mengoptimalkan modal intelektual secara mandiri maupun dalam ikatan organisasi, sehingga mau dan mampu melaksanakan kerja secara kreatif, kompetitif dan kooperatif untuk kepentingan dan kemajuan organisasi.

Perubahan diperlukan organisasi guna merespon dinamika eksternal dan memperkuat daya saingnya. Perubahan yang disyaratkan bukan hanya sekadar pada perubahan produk, aktivitas dan struktur eksternal yang dapat diamati, tetapi menyangkut juga perubahan internal organisasi (Dessler 2008). Perubahanperubahan itu meliputi tata nilai, cara berpikir, mindset, strategi dan bahkan mungkin tujuan-tujuan yang akan dicapai (Pearce 2007).

Perubahan yang cepat tidak saja dihadapi oleh industri berteknologi tinggi namun juga dihadapi oleh perusahaan menengah dan kecil serta perusahaan yang sudah mapan ataupun perusahaan yang baru berdiri (Pitts 2006). Ditengah perubahan yang cepat dan tingkat persaingan yang ketat, hanya organisasi yang mampu berubah dan belajar secara berkelanjutan akan mempunyai keunggulan kompetitif. Dalam rangka mewujudkan organisasi pembelajaran dibutuhkan sumber daya manusia yang secara konsisten mau dan mampu mengembangkan diri seiring dengan tuntutan organisasi. Anggota organisasi atau bisnis tidak cukup hanya cakap bekerja secara teknis, mereka juga dituntut untuk memiliki kemampuan intelektual, kecerdasan emosional dan kecakapan sosial.

Meskipun mengetahui bahwa pembelajaran dalam organisasi perlu secara konsisten dilaksanakan agar ada peningkatan keterampilan anggota dalam mendorong laju perubahan organisasi (perusahaan) secara cepat, namun sebagian besar perusahaan di Indonesia masih mengabaikannya. Sebagian besar perusahaan 
yang sudah memasuki organisasi pembelajaran (learning organization) adalah perusahaan konsultan multinasional (Prijono 2004). Sedangkan Usaha Kecil Menengah (UKM) masih lamban dalam melakukan perubahan organisasi dikarenakan sumber daya manusianya yang kurang siap mengikuti perubahan cepat dalam bidang teknlogi dan persaingan produk. Disinilah urgensi melakukan perubahan organisasi secara terencana dan sistematis agar UKM dapat tetap bertahan bahkan berkembang ditengah persaingan usaha yang semakin ketat.

Gambaran tersebut mengindikasikan bahwa kelambanan UKM dalam melakukan perubahan organisasi antara lain dikarenakan belum ada upaya mengoptimalkan kemampuan anggotanya melalui learning organization dalam situasi tantangan yang semakin kompleks dan persaingan yang semakin ketat. Salah satu upaya yang dapat dijalankan dalam melakukan perubahan bagi UKM adalah melalui proses pembelajaran bagi anggota organisasinya secara berkesinambungan.

Berpijak pada paparan di atas, maka petanyaan yang diajukan pada penelitian ini: (1) bagaimana implementasi learning organization pada UKM? (2) bagaimana pengaruh learning organization terhadap kemampuan indvidual? (3) bagaimana pengaruh kemampuan individual terhadap perubahan UKM dan (4) bagaimana pengaruh learning organization terhadap perubahan UKM?

\section{TELAAH PUSTAKA DAN PENGEMBANGAN HIPOTESIS}

Menurut Pedler et al. (dalam Dale 2003), learning organization merupakan suatu organisasi yang memfasilitasi pembelajaran bagi seluruh anggotanya dan secara terus menerus mentransformasi diri. Dalam hal ini, anggota-anggota organisasi secara individu terdorong untuk belajar dan mengembangkan potensi penuh mereka; memperluas budaya belajar ini sampai pada pelanggan, pemasok dan stakeholder lain yang signifikan; menjadikan strategi pengembangan sumber daya manusia sebagai pusat kebijakan bisnis; berada dalam proses transformasi organisasi secara terus menerus. Tujuan proses transformasi ini adalah agar perusahaan mampu mencari ide-ide, masalah-masalah dan peluang-peluang baru untuk pembelajaran, sehingga mampu memanfaatkan keunggulan kompetitif ditengah lingkungan bisnis yang tingkat persaingannya sangat ketat (Pedler et al., dalam Dale 2003).

Dalam learning organization, peranan organisasi sangat besar dalam memfasilitasi pembelajaran pada seluruh anggotanya dan secara terus menerus mentransformasikan diri. Pedler et al. (dalam Dale 2003) mengemukakan bahwa suatu organisasi pembelajaran bukan organisasi yang semata-mata mengikuti banyak pelatihan, namun pengembangan pada individu merupakan bagian dari konsep pembelajaran organisasi. Dalam learning organization perlu dilakukan penggabungan belajar adaptif (adaptive learning) dan belajar generatif (generative learning), yakni belajar memperbaiki kapasitas seseorang untuk mencipta (Senge 1994). Dessler (2008) menambahkan bahwa sebuah organisasi yang terus belajar 
akan terlatih untuk menciptakan, memperoleh, mentransfer pengetahuan dan memodifikasi perilakunya guna mencerminkan pengetahuan dan wawasan baru. Organisasi belajar ikut serta dalam lima kegiatan yakni pemecahan masalah sistematik, eksperimentasi, belajar dari pengalaman, belajar dari orang lain dan alih pengetahuan (Dessler 2008).

Membangun learning organization dapat dilakukan melalui lima disiplin yakni: berpikir sistemis (system thinking), penguasaan pribadi (personal mastery), model-model mental (mental models), membangun visi bersama (building share vision) dan tim pembelajaran (learning team) (Senge 1980). Lundberg (dalam Dale 2003) menyatakan bahwa pembelajaran adalah suatu kegiatan bertujuan yang diarahkan pada pemerolehan dan pengembangan keterampilan dan pengetahuan serta aplikasinya. Selain itu, pembelajaran organisasi harus mencakup keseluruhan proses transformasi pengetahuan, ketrampilan dan nilai kepada anggota organisasi sehingga mereka memahami bagaimana seharusnya berkerja dan menjalankan pekerjaan yang menjadi lingkup tanggung jawabnya.

\section{Kemampuan Individu}

Robbins dan Judge (2009) memaknai kemampuan sebagai kapasitas seseorang untuk mengerjakan berbagai tugas dalam suatu pekerjaan. Seluruh kemampuan seseorang pada dasarnya tersusun dari dua perangkat faktor yakni kemampuan intelektual dan kemampuan fisik (Robbins dan Judge 2009). Kemampuan intelektual merupakan kemampuan yang dibutuhkan untuk mengerjakan kegiatan mental. Sedangkan kemampuan fisik diperlukan untuk melakukan tugas-tugas yang menuntut stamina, kecekatan, kekuatan dan keterampilan serupa. Kedua kemampuan tersebut dapat efektif diimplementasikan dalam pekerjaan manakala terdapat kesesuaian karakteristik pekerjaan dengan spesifikasi kemampuan yang dimiliki oleh individu-individu pemangku pekerjaan tersebut (Robbins dan Judge 2009).

Dalam rangka melaksanakan tugas-tugas yang kompleks dan multidimensi seseorang membutuhkan sejumlah kemampuan agar dapat melaksanakan pekerjaan tersebut secara efektif, apalagi pada mereka yang berada pada posisi sebagai pengelola organisasi. Fayol (dalam Stoner 2008) mengidentifikasi tiga macam keterampilan dasar yang perlu dimiliki oleh individu dalam mengelola organisasi, yakni: kemampuan teknis, manusiawi dan konseptual. Sedangkan menurut Daft (2006) agar seseorang dapat mengelola organisasi secara baik, diperlukan keahlian konseptual, keahlian manusia dan keahlian teknis. Keahlian konseptual merupakan kemampuan kognitif untuk melihat organisasi secara keseluruhan dan keterkaitan diantara bagian-bagiannya. Keahlian ini melibatkan pemikiran, pengelolaan informasi dan kemampuan perencanaan. Keahlian manusia merupakan kemampuan untuk bekerja dengan dan melalui orang lain, serta secara efektif sebagai anggota kelompok. Keahlian ini diperlihatkan oleh kemampuan untuk memotivasi, 
memfasilitasi, mengkoordinasi, memimpin, berkomunikasi dan menyelesaikan konflik. Sedangkan keahlian teknis merupakan kemampuan memahami dan kefasihan dalam melakukan tugas tertentu. Keahlian teknis mencakup penguasaan metoda, teknik dan peralatan yang digunakan dalam fungsi tertentu. Untuk itulah maka organisasi perlu secara berkesinambungan meningkatkan kapasitas dan kapabilitas anggotanya agar dapat memberikan kontribusi yang optimal bagi kemajuan organisasi.

\section{Perubahan Organisasi}

Organisasi yang berkeinginan untuk tetap bertahan hidup harus menanggapi perubahan dalam lingkungannya (Daft 2006). Perubahan adalah suatu keniscayaan dalam tatanan interaksional organisasi, baik yang berasal dari dalam organisasi ataupun dari luar organisasi. Dalam lingkungan bisnis yang terus berubah, kesuksesan ataupun kegagalan organisasi pada hakekatnya disebabkan oleh aktivitas yang dilakukan oleh para karyawan, perubahan terencana dan kepedulian terhadap pengubahan perilaku-perilaku individu dan kelompok dalam organisasi itu. Sebab itu untuk memotori perubahan organisasi diperlukan orang yang bertindak sebagai katalis dan bersedia memikul tanggung jawab untuk mengelola perubahan seperti para manajer, bukan manajer, karyawan bahkan konsultan luar (Daft 2006).

Perubahan merupakan pengadopsian ide atau perilaku yang baru oleh suatu organisasi. Dorongan untuk melakukan perubahan dapat berasal dari kekuatankekuatan di luar organisasi seperti persaingan, pelanggan, pesaing baru maupun kekuatan-kekuatan internal organisasi (antara lain perubahan tujuan, rencana dan problema perusahaan) (Daft 2006). Perubahan secara terencana memerlukan komitmen semuan tingkatan dalam organisasi. Dalam sistem organisasi yang bersifat hierarkis dan topangan budaya yang bersifat paternalistik, agen perubahan biasanya dimotori oleh top manajamen. Manajer atau pimpinan organisasi berpengaruh kuat dalam mengubah perilaku bawahannya karena ditopang oleh otoritas struktural maupun keabsahan kultural (Robbins dan Judge 2009; Daft 2006 serta Pearce dan Robinson 2007).

Perubahan organisasi dapat dikelompokkan mejadi empat kategori yakni struktur, teknologi, setting fisik dan orang (Robbins dan Judge 2009). Sedangkan Daft (2006) membedakan jenis-jenis perubahan yang meliputi perubahan teknologi, produk, struktural dan budaya/manusia. Segala bentuk perubahan dalam organisasi membawa konsekuensi pada kesiapan dan kesanggupan anggotanya untuk menyesuaikan diri secara psikologis, pengetahuan dan keterampilan terkait perubahan tersebut. Perubahan organisasi dalam desain learning organization menitik beratkan pada perubahan orang, yakni melakukan perubahan pada sikap, keterampilan, pengharapan, persepsi dan atau perilaku karyawan (Desler 2008 dan Senge 1994). 
Perubahan organisasi dapat berlangsung secara alamiah maupun terencana (Stoner et al., 2008). Perubahan secara terencana dimaksudkan untuk menyiapkan seluruh anggota organisasi atau sebagian besar anggotanya menyesuaikan diri pada perubahan yang signifikan dengan sasaran dan arah organisasi. Menurut Stoner et al. (2008) perubahan yang direncanakan merupakan inovasi struktural, kebijakan atau sasaran baru, atau perubahan dalam filosofi operasi yang sengaja didesain dan diimplementasikan.

Dalam rangka melakukan perubahan secara efektif kebanyakan organisasi mengalami kegagalan antara lain karena orang tidak mau (atau tidak mampu) mengubah sikap dan tingkah laku yang sudah lama menjadi kebiasaaan (Stoner 2008). Untuk mengatasi hambatan jenis ini, Schein (1980) menawarkan model yang dapat berlaku bagi individu, kelompok dan seluruh organisasi yaitu meliputi model unfreezing, chaging dan refreezing, Model unfreezing membuat kebutuhan terhadap perubahan menjadi demikian nyata sehingga individu, kelompok, atau organisasi siap melihat dan menerima bahwa perubahan harus terjadi. Model changing, mencakup penemuan dan adopsi sikap, nilai dan tingkah laku yang baru. Sedangkan model refreezing mentransformasi pola tingkah laku baru menjadi norma lewat penguatan dan dukungan mekanisme dalam proses perubahan yang membutuhkan orang untuk memimpin atau membimbing proses perubahan.

\section{Perubahan Organisasi Dalam Desain Learning Organization}

Resistensi terhadap perubahan organisasi merupakan gejala yang tidak dapat dihindarkan, sebab orang-orang yang terbiasa dengan pola, iklim dan budaya kerja tertentu amat sulit untuk segera berubah manakala proses penyadaran melalui sosialisasi dan transformasi nilai-nilai baru tidak dilakukan secara intensif (Daft 2006 serta Robbins dan Judge 2009). Kesiapan organisasi untuk berubah dapat diidentifikasi dari aspek motivasional yang dikembangkan dalam organisasi, kesiapan sumber daya organisasi dalam menghadapi perubahan teknologi dan kebiasaan belajar yang berkembang dalam organisasi (Lehman 2002).

Perubahan organisasi memerlukan proses pengubahan sistem berpikir dari pola-pola lama yang sudah terinternalisasi melalui pembelajaran nilai-nilai baru kepada semua anggotanya secara konsisten. Anggota organisasi perlu iklim yang kondusif untuk merevitalisasi nilai, pengetahuan maupun ketrampilannya. Optimalisasi sumber daya manusia (SDM) sebagai modal dasar harus diikuti dengan pengembangan dan pembaruan kemampuan agar setiap anggota organisasi mampu merespon dan peka terhadap arah perubahan yang terjadi serta mendukung terjadinya pembaruan organisasi (Harvey dan Brown 2006). Untuk itu, learning organization merupakan sarana efektif untuk melakukan perubahan sistem berpikir maupun pola perilaku anggota organisasi (Shih dan Ching 2012) serta melakukan perubahan organisasi secara keseluruhan (Daft 2006). 
Survey yang dilakukan oleh Smith et al. (2003) pada 3241 perusahaan di Australia menunjukkan bahwa perubahan organisasi secara signifikan ditentukan oleh penerapan team working, total quality management, lean production, business process re-engineering dan learning organization. Studi yang dilakukan oleh Bates dan Khasawneh (2005) pada 28 organisasi di Yordania juga sampai pada kesimpulan bahwa budaya pembelajaran organisasi berpengaruh signifikan terhadap inovasi organisasi. Artinya bahwa melalui pembiasaan pembelajaran pada anggota organisasi akan meningkatkan kualitas pengetahuan dan ketrampilan sehingga daya kreasi anggota organisasi akan menjadi lebih baik.

H1: Learning organization berpengaruh langsung terhadap perubahan organisasi.

Reid dan Hickman (2002) menyatakan bahwa perubahan berbagai tingkatan dalam organisasi dapat terkait dengan learning organization. Melalui learning organization, individu-individu dalam organisasi berkesempatan meningkatkan kapasitas dirinya dalam bidang keterampilan maupun pengetahuan terkait dengan lingkup pekerjaannya sehingga mereka lebih mudah untuk menyesuaikan diri dengan perubahan. Lingkungan perlu direspon oleh organisasi (perusahaan) melalui penyesuaian teknologi, desain organisasi, bentuk pelayanan maupun kualitas produk. Setiap anggota organisasi perlu adaptasi melalui kesediaan menyesuaikan pengetahuan, nilai dan ketrampilan dengan rancangan perubahan organisasi.

Riset yang dilakukan Hadiyati (2007) tentang strategi mengelola perubahan melalui learning organization di lingkungan perusahaan kecil-menengah di sentra industri kecil mebel sampai pada kesimpulan bahwa learning organization cukup mendukung penciptaan suasana organisasi belajar di lingkungan perusaaan kecilmenengah bagi anggota organisasi (karyawan) dalam upaya beradaptasi dengan perubahan lingkungan.

Dalam rangka memperhatikan urgensi peningkatan kapasitas anggota organisasi bagi peningkatan kinerja organisasi secara keseluruhan, maka upaya pengembangan kinerja anggota secara individual perlu menjadi bagian dari strategi organisasi. Aplikasi dari manajemen kinerja dalam organisasi harus dapat menciptakan suasana kondusif bagi kelangsungan pembelajaran secara berkesinambungan.

Perubahan organisasi menjadi organisasi pembelajar dapat mendorong pada pengembangan kinerja baik secara individu maupun organisasi. Organisasi pembelajar adalah organisasi yang seluruh anggotanya mempunyai orientasi pada pembelajaran yang terjadi dari mulai tingkatan individu sampai ke tingkatan organisasi. Melalui perwujudan organisasi pembelajar, maka upaya pengembangan dan perbaikan kinerja individu akan menjadi bagian dari sikap dan perilaku anggota organisasi dalam menjalankan tugasnya. Semua anggota menjadikan 
belajar sebagai bagian tak terpisahkan dari pelaksanaan peran dan tugas yang menjadi tanggung jawabnya dalam organisasi.

H2: Kemampuan individu berpengaruh langsung terhadap perubahan organisasi.

Perwujudan organisasi pembelajar pada dasarnya merupakan kondisi yang menjadi prasyarat bagi pengembangan dan peningkatan kinerja individual, sebab peran individu akan menentukan keberhasilannya. Enos (2000) menyatakan peran individu dalam pengembangan kinerjanya amat penting untuk diperhatikan. Setiap program peningkatan kinerja hendaknya mendorong upaya untuk pengembangan individu sehingga kesadaran tentang perlunya peningkatan kinerja menjadi kesadaran setiap anggota organisasi.

Strategi pengembangan organisasi ke arah organisasi pembelajar (learning organization) menjadi amat penting agar peningkatan kapasitas anggota organisasi menjadi suatu bagian yang tak terpisahkan dari desain organisasi. Penataan secara sistemik atas learning organization akan dapat memberikan dorongan untuk terjadinya proses pengembangan kompetensi individual secara efektif (Ivancevich 2006).

H3: Learning organization berpengaruh langsung terhadap kemampuan individu.

\section{Populasi dan Teknik Penarikan Sampel}

Penelitian ini menggunakan mixed method yaitu kombinasi descriptive research dengan explanatory research. Descriptive research dilakukan dengan analisis data kualitatif guna menggambarkan secara mendalam permasalahan penelitian sedangkan explanatory research dilakukan untuk menguji hipotesis penelitian.

Populasi penelitian adalah seluruh usaha kecil dan menengah (UKM) yang berada di wilayah Kota Malang dengan pembatasan pada UKM yang menjalankan usaha dibidang industri kerajinan. Adapun kriteria penentuan populasi mengacu pada kriteria yang digunakan oleh Biro Pusat Statistik (BPS) yaitu UKM dengan volume penjualan $\leq$ Rp1 Milyar, modal usaha di luar tanah dan gedung $\leq$ Rp200 Juta serta terdaftar/memiliki ijin usaha dan mempunyai tenaga kerja minimal 5 sampai 99 orang.

Dalam realita lapangan, kriteria yang digunakan untuk penentuan populasi tidak dapat terpenuhi seluruhnya. Penelitian ini menyesuaikan dengan kodisi dilapangan dengan memakai kriteria modal usaha, jumlah tenaga kerja dan terdaftar di Dinas Koperasi dan UKM. Kriteria ijin usaha sengaja diabaikan mengingat banyak UKM yang skala usahanya sudah memenuhi kriteria sebagai usaha kecil menengah, namun tidak dilengkapi dengan ijin usaha. 
Selanjutnya dilakukan penarikan sampel dengan menggunakan teknik multi stages sampling melalui tahapan berikut ini.

1. Pengambilan sampel UKM dengan teknik purposive sampling berdasarkan wilayah kecamatan. Dengan mengacu pada data yang tersedia pada Dinas Koperasi dan UKM Kota Malang (2011), diketahui bahwa jumlah populasi sebanyak 395 UKM tersebar pada masing-masing kecamatan di Kota Malang, yakni Blimbing sebanyak 111, Kedungkandang sebanyak 54, Klojen sebanyak 67, Lowokwaru sebanyak 80 dan Sukun sebanyak 83 UKM.

2. Menentukan sampel secara proporsional pada masing-masing kecamatan dengan memperhatikan jumlah UKM yang berada pada wilayah kecamatan tersebut. Penentuan jumlah sampel dalam penelitian ini mengacu pada rumus Slovin (dalam Umar 2000) dengan toleransi kesalahan sebesar 5 persen maka dihasilkan jumlah sampel sebanyak 198 UKM.

Setelah jumlah sampel ditemukan sebanyak 198, langkah berikutnya adalah menghitung proporsi sampel untuk masing-masing wilayah Kecamatan dengan menggunakan formulasi sebagai berikut:

$$
\frac{\text { Populasi masing }- \text { masing kecamatan }}{\text { Jumlah populasi seluruh kecamatan }} \times \text { Sampel }
$$

Adapun jumlah sampel yang dijadikan responden penelitian pada masingmasing wilayah kecamatan adalah Blimbing sebanyak 56, Kedungkandang sebanyak 27, Klojen sebanyak 33, Lowokwaru sebanyak 40 dan Sukun sebanyak 42 UKM. Selanjutnya melakukan pengambilan secara acak unit sampel pada masing-masing wilayah kecamatan untuk dipilih menjadi responden penelitian.

\section{Definisi Operasional dan Pengukuran Variabel}

Variabel dalam penelitian ini meliputi learning organization, sebagai variabel bebas, kemampuan individu sebagai intervening variable dan perubahan organisasi sebagai variabel terikat. Adapun definisi operasional masing-masing variabel adalah sebagai berikut:

a. Learning organization (X) ialah organisasi yang senantiasa memfasilitasi setiap anggotanya untuk secara terus menerus belajar dan meningkatkan kapasitas dirinya. Kegiatan-kegiatan yang memberi kontribusi terhadap learning organization, yaitu: pemecahan masalah sistematik, eksperimentasi, belajar dari pengalaman, belajar dari orang lain dan alih pengetahuan.

b. Kemampuan individu ( $\mathrm{Z}$ ) merupakan penguasaan seseorang atas pengetahuan dan keterampilan tertentu sehingga berkemampuan optimal dalam melaksanakan pekerjaan yang menjadi tanggung jawabnya. Kemampuan tersebut meliputi aspek teknikal, pengambilan keputusan, kreativitas dan responsiveness. 
c. Perubahan organisasi (Y) adalah kesediaan organisasi untuk mengadopsi pengetahuan dan keterampilan baru sebagai wujud penyesuaian atas tutuntan internal maupun eksternal organisasi. Perubahan yang dimaksud meliputi teknologi, produk, setting fisik, sikap dan perilaku.

Pengukuran terhadap jawaban responden menggunakan skala Likert. Skala Likert merupakan metoda untuk mengukur sikap dengan menyatakan setuju atau ketidak-setujuannya terhadap subyek, obyek atau kejadian tertentu. Skala Likert umumnya menggunakan lima angka penilaian yaitu: (1) sangat tidak setuju, (2) tidak setuju, (3) netral, (4) setuju, (5) sangat setuju (Indriantoro dan Supomo 1999).

\section{Uji Validitas dan Reliabilitas}

Sebelum menggunakan kuesioner untuk menggali data pada responden, maka terlebih dulu dilakukan uji validitas dan reliabilitas instrument penelitian. Hasil uji validitas pada semua item pertanyaan kuesioner menunjukkan angka korelasi minimal 0,454 (lebih dari 0,3) dan nilai probabilitasnya maksimal 0,04 (kurang dari 0,05), sehingga dapat dikatakan semua item pertanyaan valid.

Reliabilitas adalah indek yang menunjukkan sejauh mana suatu alat pengukur dapat dipercaya atau dapat diandalkan. Adapun hasil pengujian reliabilitas dengan menggunakan Cronbach alpha menunjukkan hasil sebagaimana ditunjukkan pada Tabel 1.

Tabel 1

Hasil Uji Reliabilitas

\begin{tabular}{ccc}
\hline Variabel & Koefisien Alpha & Keterangan \\
\hline $\mathrm{X}$ & 0,85 & Reliable \\
$\mathrm{Z}$ & 0,83 & Reliable \\
$\mathrm{Y}$ & 0,84 & Reliable \\
\hline
\end{tabular}

Sumber: data primer diolah, 2014.

Dari hasil yang telah dipaparkan dapat dilihat bahwa nilai koefisien Cronbach alpha untuk semua variabel telah diatas 0,6 sehingga dapat dikatakan bahwa indikator-indikator pengampu variabel telah reliable.

\section{HASIL DAN PEMBAHASAN}

\section{Analisis Deskriptif}

Untuk memperoleh gambaran masing-masing variabel penelitian, maka berikut ini dipaparkan statistik deskriptif pada Tabel 2. Berdasarkan statistik deskriptif pada Tabel 2, diketahui bahwa learning organization maupun kemampuan individu (pengelola) mendapat respons tinggi dari responden atau dengan kata lain pengelola UKM mempunyai kapasitas individual yang baik dalam mengelola usahanya serta mau untuk terus belajar bagi peningkatan kompetensi dalam mengelola usahanya. Hal ini ditunjukkan oleh nilai rata-rata (mean) learning 
organization sebesar 4,05 sedangkan nilai rata-rata (mean) kemampuan individu sebesar 4,31 dengan standar deviasi masing-masing sebesar 0,55 dan 0,71. Sedangkan kelangsungan perubahan organisasi (UKM) tetap berjalan meskipun kurang begitu optimal, hal ini ditunjukkan oleh nilai rata-rata (mean) sebesar 3,99 dengan standar deviasi 0,66.

Tabel 2

Hasil Uji Statistik Deskriptif

\begin{tabular}{lccccc}
\hline \multicolumn{1}{c}{ Variabel } & N & Min. & Max. & Mean & St. Dev. \\
\hline Learning organization (X) & 198 & 1,00 & 5,00 & 4,05 & 0,55 \\
Kemampuan individu (Z) & 198 & 1,00 & 5,00 & 4,31 & 0,71 \\
Perubahan organisasi (Y) & 198 & 1,00 & 5,00 & 3,99 & 0,66 \\
\hline
\end{tabular}

Sumber: data primer diolah

\section{Uji Structural Equational Modelling (SEM)}

Analisis hasil pengolahan data secara full model SEM dilakukan dengan melakukan uji kesesuaian dan uji statistik. Adapun hasil pengolahan data analisis full model structural equation model (SEM) ditampilkan pada gambar.
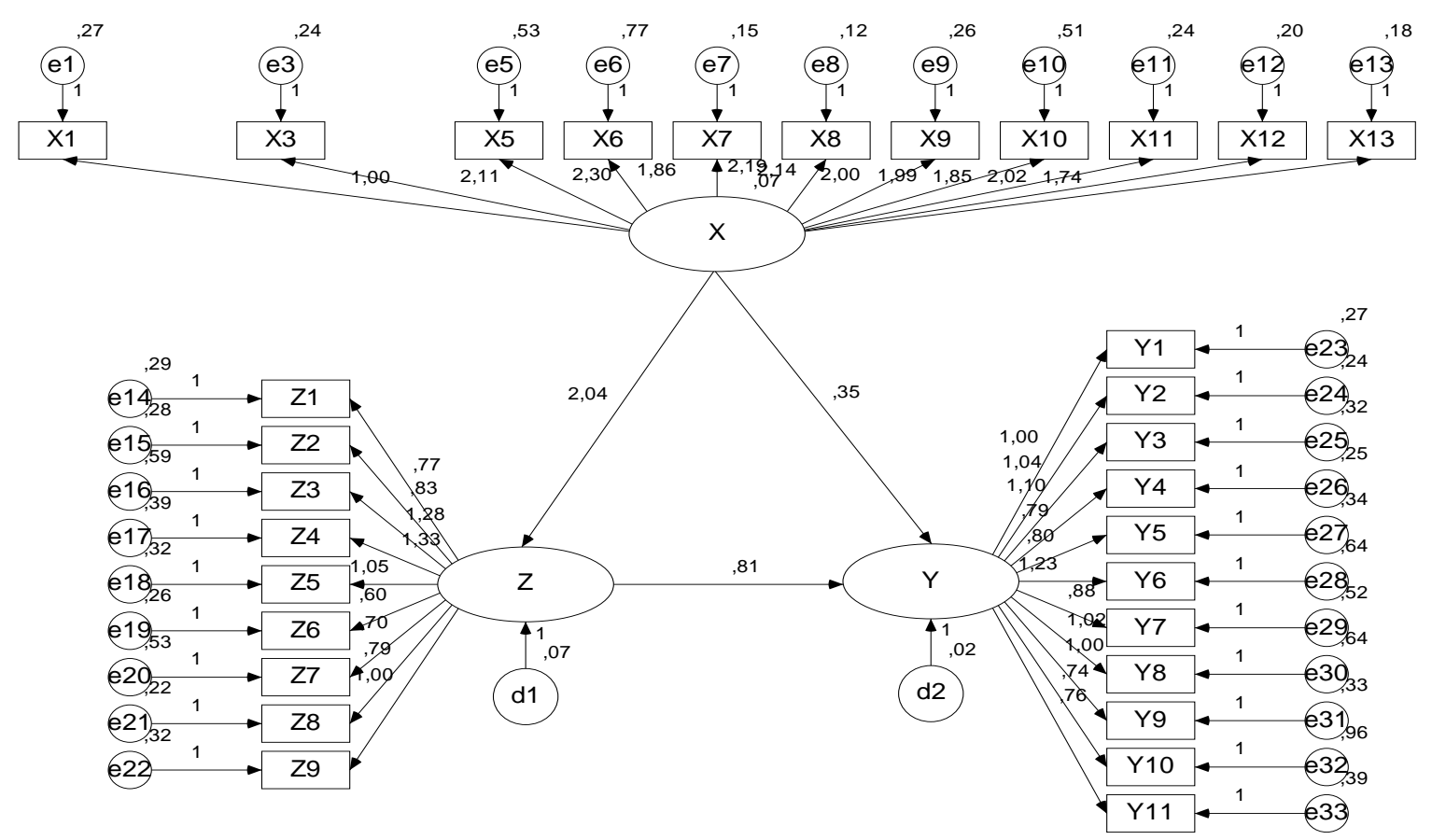

Gambar1

Analisis Full Model

Seperti halnya pada confirmatory factor analysis, maka pada pengujian structural equation model juga dilakukan uji kesesuaian model dan uji signifikansi kausalitas melalui uji koefisien regresi. Adapun hasil pengujian model SEM disajikan dalam Tabel 3. 
Tabel 3

Hasil Pengujian Kelayakan Model pada Full Model

\begin{tabular}{cccc}
\hline Goodness of Fit Index & Cut off Value & Hasil & Evaluasi Model \\
\hline Chi-Square & $\leq 480,402\left(\chi^{2}\right.$ tabel dengan & 3188,745 & Tidak Baik \\
db:431 dan p:5\%) & $\geq 0,05$ & 0,000 & Tidak Baik \\
Probability & $\leq 0,08$ & 0,07 & Baik \\
RMSEA & $\geq 0,90$ & 0,93 & Baik \\
GFI & $\geq 0,90$ & 0,89 & Marginal \\
AGFI & $\leq 2,00$ & 7,39 & Tidak Baik \\
CMIN/DF & $\geq 0,95$ & 0,97 & Baik \\
TLI & $\geq 0,95$ & 0,95 & Baik \\
CFI &
\end{tabular}

Sumber: data primer diolah, 2014

Dari Tabel 3 di atas menunjukkan bahwa nilai Chi Square $=3188,407$ dengan tingkat signifikansi sebesar 0.000 dimana ukuran fit tersebut tidak sesuai dengan cut off value. Namun, untuk ukuran model fit yang lain seperti RMSEA, GFI, AGFI, TLI dan CFI menunjukkan nilai-nilai yang sudah memenuhi kriteria fit sehingga dapat dikatakan bahwa model sudah fit. Secara keseluruhan, model dapat diterima untuk memberikan konfirmasi yang cukup untuk dapat diterimanya hipotesis unidimensionalitas bahwa kesembilan indikator diatas dapat mencerminkan variabel laten yang dianalisis.

Disamping menguji kriteria-kriteria kesesuaian model diatas, perlu juga dilakukan evaluasi terhadap ketepatan model yang lain, meliputi: evaluasi normalitas data, evaluasi reliability dan variance extract. Untuk evaluasi normalitas data diasumsikan bahwa penelitian ini memenuhi persyaratan karena 198 data yang diobservasi (lebih dari 100). Nilai reliabilitas minimum dan dimensi/indikator pembentuk variabel laten yang dapat diterima adalah sebesar 0,70. Sedangkan pengukuran variance extract menunjukkan jumlah varian dari indikator yang diekstraksi oleh konstruk/variabel laten yang dikembangkan. Nilai variance extract yang dapat diterima adalah minimal 0,50 . Hasil perhitungan reliability dan variance extract dapat dilihat pada Tabel 4.

Tabel 4

Reliability dan Variance Extract

\begin{tabular}{cccc}
\hline Variabel & Construct Reliability & Variance Extracted & Keterangan \\
\hline Learning Organization & 0,777233 & 0,590119 & Baik \\
Kemampuan Individu & 0,913064 & 0,540586 & Baik \\
Perubahan organisasi & 0,905952 & 0,47381 & Baik \\
\hline
\end{tabular}

Sumber: data primer diolah, 2014

Tabel 4 menunjukkan informasi bahwa hasil uji reliabilitas semua variabel penelitian memiliki nilai lebih dari 0,70 dan nilai variance extract dari semua variabel lebih dari 0,50. Hasil ini memberikan makna bahwa alat ukur penelitian termasuk dalam kategori baik (layak) untuk digunakan. 


\section{Hasil Uji Hipotesis}

Setelah melakukan penilaian terhadap asumsi-asumsi yang ada pada SEM, selanjutnya akan dilakukan pengujian hipotesis. Pengujian ketiga hipotesis penelitian ini dilakukan berdasarkan nilai critical ratio (CR) dari hubungan kausalitas antar variabel. Adapun hasil pengujian hipotesis penelitian dipaparkan pada Tabel 5.

Tabel 5

Rangkuman Hasil Uji Hipotesis $1\left(\mathrm{H}_{1}\right)$ sampai Hipotesis $3\left(\mathrm{H}_{3}\right)$

\begin{tabular}{|c|c|c|c|c|c|c|c|c|}
\hline \multicolumn{3}{|c|}{ Hipotesis } & \multirow{2}{*}{$\begin{array}{r}\begin{array}{c}\text { Std } \\
\text { Estimate }\end{array} \\
0,975\end{array}$} & \multirow{2}{*}{$\begin{array}{c}\text { Estimate } \\
1,791\end{array}$} & \multirow{2}{*}{$\begin{array}{r}\boldsymbol{S E} \\
0,293\end{array}$} & \multirow{2}{*}{$\begin{array}{r}\boldsymbol{C R} \\
6,121\end{array}$} & \multirow{2}{*}{$\begin{array}{c}\mathbf{P} \\
* * *\end{array}$} & \multirow{2}{*}{$\begin{array}{c}\text { Label } \\
\text { par_28 }\end{array}$} \\
\hline $\begin{array}{l}\text { Kemampuan } \\
\text { Individu }\end{array}$ & $<---$ & $\begin{array}{l}\text { Learning } \\
\text { Organization }\end{array}$ & & & & & & \\
\hline $\begin{array}{l}\text { Perubahan } \\
\text { Organisasi }\end{array}$ & $<---$ & $\begin{array}{l}\text { Learning } \\
\text { Organization }\end{array}$ & 2,293 & 2,709 & 1,215 & 2,235 & 0,037 & par_29 \\
\hline $\begin{array}{l}\text { Perubahan } \\
\text { Organisasi }\end{array}$ & $<---$ & $\begin{array}{l}\text { Kemampuan } \\
\text { Individu }\end{array}$ & 2,217 & 2,574 & 1,111 & 2,318 & 0,020 & par_30 \\
\hline
\end{tabular}

Sumber: data primer diolah, 2014

Dari Tabel 5 dapat diketahui bahwa variabel learning organization mempunyai pengaruh langsung terhadap kemampuan individu, variabel kemampuan individu berpengaruh terhadap perubahan organisasi dan variabel learning organization berpengaruh terhadap perubahan organisasi. Hal ini ditunjukkan oleh nilai $C R$ lebih dari dua dan nilai $\mathrm{P}$ kurang dari 0,05.

\section{PEMBAHASAN}

\section{Pengaruh Langsung Learning Organization Terhadap Kemampuan Individu}

Hipotesis pertama yang menyatakan bahwa learning organization berpengaruh langsung terhadap kemampuan individual didukung oleh hasil penelitian ini. Hal ini nampak dari nilai koefisien standar learning organization terhadap kemampuan individu adalah positif dan signifikan pada probabilitas $=0,000$ $(\mathrm{p}<0,05)$, berarti bahwa learning organization berpengaruh langsung dan searah terhadap kemampuan pengelolaan UKM. Tanda positif dan siginifikan pada koefisien standar menunjukkan bahwa semakin intensif learning organization maka semakin meningkat pula kemampuan seseorang dalam mengelola UKM. Untuk dapat meningkatkan kemampuan di bidang pengelolaan bisnis (UKM) diperlukan proses belajar yang berkesinambungan. Melalui belajar berkesinambungan seseorang dapat meningkatkan pengetahuan dan ketrampilan dalam mengelola organisasi (UKM). Temuan penelitian ini sejalan dengan hasil penelitian Reagans et al. (2005) bahwa pembelajaran pada perusahaan berpengaruh pada kecakapan seorang pekerja, peningkatan kemampuan anggota organisasi dalam hal akumulasi pengetahuan serta kapasitas melakukan koordinasi dalam organisasi.

Pengaruh signifikan learning organization terhadap kemampuan individu menunjukkan adanya kecenderungan peningkatan pengetahuan maupun keterampilan 
dalam mengelola UKM setelah mengikuti serangkaian pendidikan maupun pelatihan. Hal ini berarti bahwa pengelola UKM telah memahami pentingnya belajar secara berkelanjutan dalam hal-hal yang terkait dengan pengelolaan organisasi. Hal-hal tersebut meliputi pemecahan masalah, pengambilan keputusan, melakukan uji coba pada produk baru agar menghasilkan produk yang berkualitas, melakukan sharing dengan rekan seprofesi maupun diluar profesi dalam upaya untuk meningkatkan kemampuan individu pengelola baik secara teknikal maupun konseptual. Urgensi learning organization dalam meningkatan kapasitas individu pengelola tercermin dari tanggapan yang diberikan oleh responden bahwa learning organization dan kemampuan individu mendapat respon tinggi dari pengelola UKM. Peningkatan kemampuan individual anggota organisasi bisa dirancang secara sistematis melalui learning organization sehingga masing-masing anggota organisasi pada tingkatan manapun dalam organisasi dapat meningkatkan kapabilitas dirinya. Hasil temuan penelitian ini didukung oleh Senge (1994), Borthick et al. (2003), Dale (2003) dan Robbins dan Judge (2009).

Apabila dilakukan kajian atas hasil jawaban responden sebagaimana termuat dalam hasil analisis konfirmatori, terindikasi bahwa pengaruh terkuat dalam pembentukan variabel learning organization adalah indikator belajar dari pengalaman. Temuan hasil penelitian tersebut sesuai dengan pendapat Garvin (2000) bahwa karakteristik yang melekat pada learning organization antara lain adalah aspek pemecahan masalah dan pembelajaran dari pengalaman yang pernah dilakukannya sendiri.

\section{Pengaruh Kemampuan Individu terhadap Perubahan Organisasi}

Hipotesis kedua yang menyatakan bahwa kemampuan individu berpengaruh langsung terhadap perubahan organisasi didukung oleh hasil penelitian ini. Hal ini nampak dari nilai koefisien standar kemampuan individu terhadap perubahan organisasi adalah positif dan signifikan pada probabilitas $=0,020(\mathrm{p}<0,05)$, yang berarti bahwa kemampuan individu berpengaruh langsung dan searah terhadap perubahan organisasi (UKM). Tanda positif dan siginifikan pada koefisien standar menunjukkan bahwa semakin berkualitas kemampuan individu pengelola UKM maka semakin mudah organisasi (UKM) melakukan perubahan.

Dalam upaya melakukan perubahan UKM diperlukan kemampuan yang memadai pada pengelola UKM. Sebab, untuk memotori perubahan organisasi diperlukan orang yang bertindak sebagai katalis dan bersedia memikul tanggung jawab untuk mengelola perubahan. Dalam sistem organisasi yang bersifat hierarkis dan topangan budaya paternalistik, agen perubahan biasanya dimotori oleh manajemen puncak. Manajer atau pimpinan organisasi berpengaruh kuat dalam mengubah perilaku bawahannya karena ditopang oleh otoritas kultural maupun keabsahan kultural (Robbins dan Judge 2009; Pearce dan Robinson 2007). Hal ini diperkuat oleh hasil penelitian Sampson (1999) yang menunjukkan bahwa perubahan 
organisasi antara lain ditentukan oleh tingkat pengetahuan dan penguasaan teknologi yang dimiliki oleh angggota organisasi. Dalam konteks ini pimpinan organisasi berperan penting untuk memfasilitasi perubahan tersebut melalui desain program organisasi yang mempercepat perubahan tersebut.

\section{Pengaruh Learning Organization terhadap Perubahan Organisasi.}

Hipotesis ketiga yang menyatakan bahwa learning organization berpengaruh langsung terhadap perubahan organisasi didukung oleh hasil penelitian ini. Hal ini nampak dari nilai koefisien standar learning organization terhadap perubahan organisasi adalah positif dan signifikan pada probabilitas $=0,037(\mathrm{p}<0,05)$, berarti bahwa learning organization berpengaruh langsung dan searah terhadap perubahan organisasi (UKM). Tanda positif dan siginifikan pada koefisien standar menunjukkan bahwa semakin tinggi intensitas learning organization dilaksanakan dalam organisasi UKM maka semakin mudah organisasi (UKM) melakukan perubahan.

Perubahan UKM memerlukan anggota organisasi untuk mengubah sistem berpikir, sikap dan perilakunya dalam merespon dinamika internal maupun eksternal organisasi. Perubahan tuntutan konsumen atas kualitas produk maupun desain serta tata pengelolaan organisasi yang semakin profesional mengharuskan semua anggota organisasi untuk bisa beradaptasi dengan kondisi tersebut. Perubahan perilaku yang lebih responsif terhadap dinamika organisasi, antara lain dapat dilakukan melalui kesediaan untuk belajar secara berkelanjutan. Disinilah urgensi learning organization dalam perubahan suatu organisasi, termasuk UKM. Learning organization akan menunjang kemampuan individual maupun kolektif anggota organisasi untuk berubah ke arah yang lebih berkualitas dan memiliki daya adaptasi terhadap lingkungan eksternalnya (Sange (1998) dan Farago (1995)). Selain itu, learning organization juga akan mendorong organisasi untuk lebih adaptif terhadap perubahan dikarenakan daya dukung manusianya mempunyai kapabilitas yang memadai untuk merespon perubahan internal maupun eksternal (Dale 2003).

Urgensi learning organization dalam melakukan perubahan organisasi (UKM) tercermin dari respon yang tinggi terhadap learning organization dan perubahan organisasi dari responden. Keseluruhan aspek learning organization mengarah pada keinginan untuk selalu memperhatikan kemajuan kapasitas anggota organisasi menjadi lebih baik sehingga melalui pembelajaran pada semua lini diharapkan secara individual maupun kolektif mempunyai kemampuan untuk berkontribusi pada perubahan organisasi. Hasil penelitian Dessler (2008) serta Robbins dan Judge (2009) sepakat dengan temuan penelitian ini.

\section{SIMPULAN}

Berdasarkan pada hasil penelitian dan uji statistik sebagaimana yang telah dipaparkan sebelumnya, maka simpulan yang dapat ditarik dari penelitian ini adalah 
sebagai berikut: (1) learning organization berpengaruh positif dan signifikan terhadap kemampuan individu. Hasil tersebut mengindikasikan bahwa semakin intensif learning organization diimplementasikan dalam UKM, maka akan semakin meningkat kemampuan individu dalam mengelola UKM. (2) Kemampuan individu berpengaruh positif dan signifikan terhadap perubahan organisasi, yakni semakin baik kualitas kemampuan individu dalam mengelola UKM maka, akan semakin responsif terhadap upaya perubahan organisasi. (3) Learning organization berpengaruh positif dan signifikan terhadap perubahan organisasi, yakni semakin intensif learning organization diimplementasikan dalam UKM, maka akan semakin kuat daya adaptasi UKM tersebut atas dinamika internal internal maupun eksternal organisasi.

Sedangkan rekomendasi yang diajukan dalam penelitian ini meliputi: (1) learning organization yang telah dilaksanakan oleh UKM di Kota Malang Raya perlu untuk dipertahankan, bahkan lebih diintensifkan lagi agar kemampuan pemilik dalam mengelola UKM menjadi lebih baik; (2) pemilik atau pengelola UKM perlu segera melakukan perubahan secara organisasional seiring dengan perubaan internal ataupun eksternal organisasi; (3) intensitas learning organization perlu dipertahankan bahkan ditingkatkan pelaksanaannya dalam UKM seiring dengan upaya untuk melakukan perubahan dalam organisasi (UKM).

\section{DAFTAR PUSTAKA}

Bates, R., dan S. Khasawneh. 2005. Organizational learning culture, learning transfer climate and perceived innovation in Jordanian organizations. International Journal of Training and Development. Vol.9 No.2: 57-69.

Borthick, A. F., D. R. Jones, dan S. Wakai. 2003. Designing learning experiences within learners' zones of proximal development (ZPDs): enabling collaborative learning on-site and online. Journal of Information Systems. Vol.17 No.1: 107-134.

Chien, S. Y., dan C. H. Sai. 2012. Dynamic capability, knowledge, learning, and firm performance. Journal of Organizational Change Management. Vol.25 No.3: $434-444$.

Daft, R. L. 2006. Manajemen. Edisi 6. Jakarta: Salemba Empat.

Dale, M. 2003. Developing Management Skill (Terjemahan). Jakarta: PT Gramedia.

Dessler, G. 2008. Human Resource Management. $11^{\text {rd }}$ Ed. New Jersey: Pearson Prentice-Hal.

Enos, D. D. 2007. Performance Improvement: Making it Happen. $2^{\text {rd }}$ Ed.

Garvin, D. A. 2000. Learning in Action: A Guide to Putting The Learning Organization to Work. USA: Harvard Business School Press. 
Harvey, D., dan D. Brown. 2006. An Experimental Approach to Organizational Development. $7^{\text {th }}$ Ed. Pearson Education.

Hadiyati, U. 2007. Strategi mengelola perubahan melalui learning organization di lingkungan perusahaan kecil-menengah sentra industri kecil mebel rotan. Manajemen Usahawan. Vol.1: 42-53.

Ivancevich, J. M. 2006. Human Resource Management. USA: McGraw-Hill Irwin.

Indriantoro, N., dan B. Supomo. 1999. Metodologi Penelitian Bisnis: Untuk Akuntansi \& Manajemen. Yogyakarta: BPFE.

Lehman, W. E. K. 2002. Assesing organizational readness for change. Journal of Subtance Abuse Treatment. Vol.22: 197-209.

Madan, P., dan S. Khanka. 2010. Contribution of knowledge management practices in creating sustainable competitive advantage for business schools in India. Journal of Information \& Knowledge Management. Vol.9 No.4: 387-397.

Pearce, J. A., dan R. B. Robinson. 2007. Strategic Management: Formulation, Implementation and Control. $10^{\text {rd }}$ Ed. . New York: Mc.Graw-Hill.

Pitts, R. A., dan D. Lei. 2006. Strategi Management: Building and Sustaining Competitive Advantage. Thomson-South Western.

Prijono,T. 2004. Konsep pengembangan SDM menghadapi perubahan tantangan organisasi. Manajemen Usahawan. Vol.2: 28-31.

Reagan, R., L. Argote, dan D. Brooks. 2005. Individual experience and experience working together: predicting learning rates from knowing who knows what and knowing how to work together. Management Science. Vol.51: 869-881.

Reid, B., dan P. Hickman. 2002. Are housing organisations becoming learning organisations? Some lessons from the management of tenant participation. Housing Studies. Vol.17: 895-918.

Robbins,S. P., dan J. A. Timothy. 2009. Organizational Behavior $13^{\text {rd }}$ Ed. New Delhi: Pearson Prentice-Hall.

Sampson, D., dan M. Terziovski. 1999. The relationship between total quality management practices and operational performance. Journal of Operations Management. Vol.17: 339-409.

Schein, E. 1990. Organizational Psychology $5^{\text {th }}$ Edition. Englewood Cliffs, N.J. New Jersey: Prentice Hall.

Senge, P. M. 1994. The Fifth Dicipline: The Art and Practice of Learning Organization. New York: Double. D.

Stonner, J. A. F., R. E. Freeman, dan D. R. Gilbert Jr. 2008. Management $6^{\text {th }}$ Ed. Englewood Cliftts, New Jersey: Prentice-Hall Inc. 
Smith, A., E. Oczkowski, R. Macklin, dan C. Noble. 2003. Organisational change and the management of training in Australia enterprises. International Journal of Training and Management. Vol.7 No.1: 2-15.

Umar, H. 2000. Metode Penelitian Aplikasi dalam Pemasaran. Jakarta: Gramedia Pustaka Persada. 